\title{
A New Solvent Extraction Method with Gas Chromatography-Mass Spectrometry for Bisphenol A Determination in Canned Foods
}

\author{
S. Arar ${ }^{*}$ and M. Alawi \\ Department of Chemistry, School of Science, The University of Jordan, Amman-11942, Jordan
}

Received: 24 September 2017; accepted: 08 October 2017

\begin{abstract}
A new reliable simple solvent extraction method for the endocrine disruptor bisphenol A (BPA) in canned food was developed employing an aqueous basic extraction solution of $0.25 \mathrm{M} \mathrm{K}_{2} \mathrm{CO}_{3} / 0.10 \mathrm{M} \mathrm{NaOH}$ after spiking with BPA-d $\mathrm{d}_{16}$ as internal standard. The BPA was next extracted into diethyl ether after solution acidification to $\mathrm{pH}=4$ and filtration. Homogenous acetylation at dry basic conditions (acetic anhydride as derivatization agent and solvent with sodium acetate as catalyst) after diethyl ether evaporation was carried out for 30 min at $110{ }^{\circ} \mathrm{C}$. Detection of the acetylated BPA was carried out by gas chromatography-electrospray ionization/mass spectrometry (GC-EI/MS) in the selected ion monitoring (SIM) mode with pulsed split-less mode. The method was applicable in terms of eliminating the use of solvents like acetonitrile for the extraction step, where relatively long evaporation times may have been needed to evaporate acetonitrile. Also, removing lipids and precipitating most of the proteins at acidic conditions $(\mathrm{pH}=4)$ prior to diethyl ether extraction can replace the often used heptane or hexane or solid sorbents. The method was tested linear with limit of linearity $(\mathrm{LOL}=750 \mu \mathrm{g} / \mathrm{L})$ and with coefficient of determination $\left(R^{2}=0.998\right)$, repeatable with relative standard deviation (RSDr $<7 \%$ ) with instrument detection limit (IDL) of $0.01 \mu \mathrm{g} / \mathrm{L}$ and limit of quantitation (LOQ) of $0.034 \mu \mathrm{g} / \mathrm{L}$. The method detection limit (MDL) ranged from $0.3 \mu \mathrm{g} / \mathrm{kg}$ to $3.2 \mu \mathrm{g} / \mathrm{kg}$ based on $1 \mathrm{~g}$ sample (wet weight). Recovery ranged from $85 \%$ to $94 \%$ with the relative standard deviations of $2 \%-13 \%$. BPA concentrations in tested canned foods from outlet stores ranged from $<$ MDL to $57.4 \pm(2.6) \mu \mathrm{g} / \mathrm{kg}$ which were below the specific limit for BPA migration in food proposed by the European Union (EU) and within the food safety and quality criteria. The extraction and derivatization steps for BPA were unique and have not been reported in literature.
\end{abstract}

Keywords: Bisphenol A, canned food, acetylation, alkaline solution, solvent extraction

\section{Introduction}

Bisphenol A (BPA) is an organic synthetic compound with the chemical formula $\mathrm{C}_{15} \mathrm{H}_{16} \mathrm{O}_{2}$ and structural formula as in Figure $\mathrm{S} 1$ belonging to the group of diphenylmethane derivatives and bisphenols, with two hydroxyl-phenyl groups [1]. World production is now about six million tons per year as pointed out in the Food and Agriculture Organization/World Health Organization (FAO/WHO) Expert Meeting on bisphenol A (BPA) sources and occurrence in Ottawa, Canada [2]. Most of it is used for the production of the polycarbonate used to make water bottles and many other consumer products requiring a clear plastic and resins such as the material used to line food cans to prevent corrosion [3], which ultimately leaches from can lining into food by contact during processing and production, storage conditions, and can lining decay by time [4]. Bisphenol $\mathrm{A}$ is an endocrine disruptor - a substance which interferes with the production, secretion, transport, action, function, and elimination of natural hormones [5, 6]. BPA can imitate our body's own hormones in a way that could be hazardous for health [7]. Also, babies and young children are said to be especially sensitive to the effects of BPA [8]; these harmful effects of BPA urged governmental and consumer health agencies to investigate the presence of BPA in food and set related regulations (BPA No-Observable-Adverse-Effect Level [NOAEL], $1 \mathrm{mg} / \mathrm{kg}$ bw/day, total daily intake [TDI] of $50 \mu \mathrm{g} / \mathrm{kg} /$ day) $[2,9]$. Many different analytical methods were proposed and conducted for the detection and determination of BPA in canned food and other matrices employing different extraction, purification, derivatization approaches, and methods, with different instrumental

\footnotetext{
* Authors for correspondence: s.arar@ju.edu.jo, alawima@ju.edu.jo
}

detection methods [1,9]. All developed and adapted methods were aiming to be simple, reaching low limits of detection (LODs), accurate, precise, and cover adequate range of BPA concentrations. Liquid chromatography methods (liquid chromatography [LC], high-performance liquid chromatography [HPLC], or ultra-performance liquid chromatography [UPLC]) coupled to different detectors including ultraviolet (UV), fluorescence (FL), electrochemical detection (ECD), mass spectrometry (MS), and tandem mass spectrometry (MS/MS) were developed, validated, and adapted to determine BPA in different food matrices with different extraction approaches as summarized by Cao [1,9] and Voutsa [10]. Recently, Rozaini et al. [11] used rapid ultrasound-assisted emulsification microsolid-phase extraction based on molecularly imprinted polymer for HPLC-diode array detection (DAD) determination of bisphenol $\mathrm{A}$ in aqueous matrices. In 2017, Cunha and coworkers [12] developed QuEChERS-based extraction and liquid chromatography-tandem mass spectrometry method for simultaneous quantification of bisphenol A and tetrabromobisphenol A in seafood: fish, bivalves, and seaweeds. Pasquale and coworkers [13] determined BPA, bisphenol B (BPB), bisphenol $\mathrm{F}$ (BPF), bisphenol A diglycidyl ether (BADGE), and bisphenol $\mathrm{F}$ diglycidyl ether (BFDGE) in canned energy drinks by molecularly imprinted polymer cleaning up and UPLC with fluorescence detection. Other groups used and developed methods based on solid-phase microextraction, QuEChERS-like liquid-liquid partition in the presence of salts, magnetic solidphase extraction, and vortex-assisted supramolecular microextraction employing HPLC and LC-MS [14-19]. Gas chromatography (GC) coupled to MS, flame ionization detector (FID), or ECD for BPA detection using different extraction procedures till 2013 are also well summarized by Cao [1,9] and Voutsa [10]. Using GC for BPA and other semi- and non-volatile compounds

This is an open-access article distributed under the terms of the Creative Commons Attribution-NonCommercial 4.0 International License (https://creativecommons.org/licenses/by-nc/4.0/), which permits unrestricted use, distribution, and reproduction in any medium for non-commercial purposes, provided the original author and source are credited, a link to the CC License is provided, and changes - if any - are indicated. 
determination mandates a derivatization step [20]; this derivatization step involves chemical modification of the chemical compound to produce a new compound with properties suitable for GC analysis (less polarity, higher volatility, higher stability, and higher peak efficiency and detectability) [21]. This is achieved by employing different derivatization approaches like alkylation [22], silylation [23], and acylation [24] where product stability and percent yield depends on reaction conditions and reagents used [20, 21]. Recently, Cesen and coworkers [25] determined bisphenols and related compounds in honey and their migration from selected food contact materials using Oasis HLB cartridges, silylated and analyzed by GC-MS. In 2015, Cao and coworkers [26] reported levels and temporal trend of bisphenol A in composite food samples from Canadian total diet study 2008-2012 using the same procedure used previously in 2008 by Cao [27]. Where BPA was extracted with acetonitrile after spiking sample with BPA- $\mathrm{d}_{16}$, followed by a buffering step to $\mathrm{pH}=7$ and cleaning on $\mathrm{SPE}_{18}$ cartridge. This was followed by an acetylation step at room temperature with emulsion of $1.0 \mathrm{M} \mathrm{K}_{2} \mathrm{CO}_{3}$, acetonitrile, acetic anhydride, and extraction with isooctane (provided a combination of derivatization and extraction of the reaction product). Cunha et al. (2013) [28] assisted bisphenol A and bisphenol B in canned vegetables and fruits by gas chromatography-mass spectrometry after QuEChERS and dispersive liquid-liquid microextraction (DLLME), where the DLLME procedure involved the use of tetrachloroethylene as extractive solvent while the own acetonitrile extract obtained from QuEChERS was used as dispersive solvent and acetic anhydride as derivatizing reagent (heterogeneous reaction conditions). Fontana et al. (2011) [29] developed an ultrasound-assisted emulsification microextraction in situ derivatization (USAEMEISD) with acetic anhydride for the one-step derivatization, extraction, and pre-concentration of BPA in beverage samples prior to its determination by GC-MS. In this study, we have introduced a new simultaneous solvent extraction and cleaning procedure (excluding organic solvents like acetonitrile or methanol for BPA extraction, and hexane, or heptane for proteins and lipids removal) which is different from the aforementioned procedures. Also, acetylation reaction (derivatization) conditions also excluded the use of dispersive solvents like acetonitrile in the absence of water. The extraction and derivatization steps for BPA were unique and have not been reported in literature. Canned food is initially extracted into alkaline medium (BPA is highly soluble in this medium) and filtered, and then filtrate was followed by $\mathrm{pH}$ adjustment to 4 to precipitate proteins. This guarantees that extract is free from all lipophilic proteins and lipids with eliminating the need of solvents like acetonitrile, hexane, and heptane for the extraction and cleanup steps. This was followed by diethyl ether selective extraction to BPA leaving behind water soluble compounds including carbohydrates, followed by further acetylation step (diethyl ether is evaporated in few min to dryness) for $30 \mathrm{~min}$ at $110^{\circ} \mathrm{C}$. The acetylated BPA is monitored quantitatively in the $\mathrm{GC}-\mathrm{EI} / \mathrm{MS}$ in the selected ion monitoring (SIM) mode. To our knowledge, this solvent extraction procedure accompanied with a further acetylation step in dry conditions and detection using GC-EI/MS in SIM mode accompanied with the pulsed split-less mode has not been reported in literature.

\section{Experimental}

Chemicals and Solvents. BPA (purity $>99 \%$ ), BPA- $d_{16}$ (98 atom \% D), acetic anhydride (min. assay 99\%), and sodium sulfate (AR, anhydrous min. assay $99.9 \%$ ) were purchased from Sigma-Aldrich (USA). Dichloromethane (GC grade, min. assay 99.9\%), hexane (min. assay 99.5\%), and ethyl ether anhydrous (min. assay 99.9\%) were purchased from TEDIA (USA). Sodium acetate (min. assay 99.9\%) was purchased from
Gainland Chemical Company, UK, sodium hydroxide pellets (ACS grade, min. assay $98.5 \%$ from Scharlu), potassium carbonate (ACS grade, min. assay 99\% from BDH chemicals/ UK), and water (HPLC grade from Fisher Scientific/USA). Sodium sulfate was heated at $300{ }^{\circ} \mathrm{C}$ in a muffle furnace (Carbolite model ELF 11/6B/UK).

Sampling. Thirty food cans with different brand names and contents were bought from food outlet stores in AmmanJordan representing most used items at shelves. Labeling detailed information about each food can was recorded including carbohydrate/sugar, protein content, fat, sodium, and calcium content, in addition to net weight and expiry date. The $\mathrm{pH}$ of each food sample was measured, and cans were classified as 2-piece can or 3-piece can and which piece surface is lacquered with the grey-white coating responsible for the BPA migration to food as described in Table 1. Purchased food cans were stored at laboratory shelves, and then each can was opened where all the food contents were homogenized with Warning two-speed laboratory blender (120 Vac model, USA). A 1-10 g portion when necessary was taken for the extraction step, where $50 \%$ of the samples were portioned in duplicate. The rest of the homogenized food was returned to the same can with lid and wrapped with aluminum foil and kept in freezer at $-20{ }^{\circ} \mathrm{C}$.

Sample Preparation. All glassware was previously heated to $220{ }^{\circ} \mathrm{C}$ to eliminate any possible contamination with BPA and rinsed with ethanol or acetone if necessary. Also, the stainless steel blender container, after homogenizing each sample using Warning two-speed laboratory blender (120 Vac model, USA) was washed well with detergent, rinsed well with tap water and deionized water, and then rinsed with ethanol and dried with air dryer. A $1-10$ g portion (wet weight) of each prehomogenized sample was spiked with $400 \mu \mathrm{L}$ of $100 \mu \mathrm{g} / \mathrm{L}$ BPA- $\mathrm{d}_{16}$ and addition of $20.0 \mathrm{~mL}$ of $0.25 \mathrm{M} \mathrm{K}_{2} \mathrm{CO}_{3} / 0.1 \mathrm{NaOH}$ followed by blending and mixing for $2 \mathrm{~min}$ and left to stand for $5 \mathrm{~min}$. The aqueous alkaline extract was filtered using suction filtration employing a fritted glass funnel, and then, the solid sample residue was washed with $15.0 \mathrm{~mL}\left(0.25 \mathrm{M} \mathrm{K}_{2} \mathrm{CO}_{3} /\right.$ $0.1 \mathrm{NaOH})$. The $\mathrm{pH}$ of the pooled filtrate was adjusted to 4 using $1.2 \mathrm{M} \mathrm{HCl}$ and transferred into a $250.0 \mathrm{~mL}$ separatory funnel where there it was extracted with two portions of $20.0 \mathrm{~mL}$ diethyl ether. The ether upper layer was removed and transferred to a beaker containing sodium sulfate. The dry ether layer was decanted into a second dry beaker and left on a hot plate $\left(30{ }^{\circ} \mathrm{C}\right)$ to evaporate to dryness. The walls of the dry beaker were then rinsed with $5.0 \mathrm{~mL}$ diethyl ether, and the contents were transferred into a $10 \mathrm{~mL}$ reaction vial (Reacti-vial Thermo, USA) where diethyl ether was evaporated using a gently stream of nitrogen at $40{ }^{\circ} \mathrm{C}$. Three milliliters $(3 \mathrm{~mL})$ of acetic anhydride and $0.5 \mathrm{~g}$ sodium acetate (excess amounts to make acetylating conditions basic) were added to the reaction vial, and then, it was sealed tightly with screw cap and heated on thermo heating block (Reacti-Vap-Evaporator model, Thermo Fisher Scientific, USA) at $110{ }^{\circ} \mathrm{C}$ for $30 \mathrm{~min}$. After cooling down, reaction was quenched with water (to destroy excess acetic anhydride and remove excess catalyst), and the acetylated BPA and BPA- $\mathrm{d}_{16}$ were extracted with two portions of $2.0 \mathrm{~mL}(50 \%: 50 \%)$ hexane-dichloromethane and passed through sodium sulfate columns into $10 \mathrm{~mL}$ conical bottom centrifuge tubes. The hexane-dichloromethane mixture was evaporated into to dryness under using a stream of nitrogen, and then, $200 \mu \mathrm{L}$ hexane-dichloromethane was added to the tube followed by agitation on vortex mixer (KMC-1300 V from Vision Scientific Co. Ltd.) for $30 \mathrm{~s}$ and then transferred into GC vial with $250 \mu \mathrm{L}$ insert for GC-EI/MS analysis. Method blank is prepared by taking $1-10 \mathrm{~g}$ of $0.25 \mathrm{M} \mathrm{K}_{2} \mathrm{CO}_{3} /$ $0.1 \mathrm{NaOH}$ and applying the above mentioned procedure. 
Table 1. Method detection limits and percent recoveries of BPA in different food matrices

\begin{tabular}{|c|c|c|c|c|}
\hline Food type & $\begin{array}{c}\text { BPA spiking } \\
\text { concentration }(\mu \mathrm{g} / \mathrm{kg})\end{array}$ & $\begin{array}{l}\text { MDL } \\
(\mu \mathrm{g} / \mathrm{kg})\end{array}$ & $\begin{array}{c}\text { BPA spiking } \\
\text { concentration }(\mu \mathrm{g} / \mathrm{kg})\end{array}$ & $\begin{array}{l}\text { Percent average } \\
\text { recovery } \pm \text { RSD* }\end{array}$ \\
\hline \multirow{3}{*}{ Homemade chick peas } & 0.40 & 0.30 & 90 & $94 \pm 6$ \\
\hline & & & 60 & $93 \pm 3$ \\
\hline & & & 30 & $91 \pm 4$ \\
\hline \multirow[t]{3}{*}{ Homemade Medames Fava Beans } & 0.40 & 0.40 & 90 & $91 \pm 4$ \\
\hline & & & 60 & $93 \pm 3$ \\
\hline & & & 30 & $90 \pm 5$ \\
\hline \multirow[t]{3}{*}{ Condensed milk from farm } & 5.00 & 3.18 & 60 & $91 \pm 9$ \\
\hline & & & 30 & $90 \pm 11$ \\
\hline & & & 5 & $88 \pm 13$ \\
\hline \multirow[t]{3}{*}{ Sausages from Butchery } & 3.00 & 1.20 & 10 & $89 \pm 4$ \\
\hline & & & 5 & $88 \pm 5$ \\
\hline & & & 3 & $87 \pm 3$ \\
\hline \multirow[t]{3}{*}{ Sliced beets } & 1.00 & 0.80 & 10 & $89 \pm 6$ \\
\hline & & & 5 & $90 \pm 3$ \\
\hline & & & 1 & $88 \pm 5$ \\
\hline \multirow{3}{*}{ Chili made with organic black beans and spice } & 0.40 & 0.40 & 10 & $94 \pm 6$ \\
\hline & & & 5 & $92 \pm 4$ \\
\hline & & & 1 & $90 \pm 4$ \\
\hline \multirow[t]{3}{*}{ Rice and beans } & 0.40 & 0.38 & 10 & $93 \pm 6$ \\
\hline & & & 5 & $91 \pm 4$ \\
\hline & & & 1 & $90 \pm 6$ \\
\hline \multirow[t]{3}{*}{ Sardines } & 5.00 & 2.52 & 30 & $86 \pm 9$ \\
\hline & & & 10 & $88 \pm 11$ \\
\hline & & & 5 & $84 \pm 8$ \\
\hline \multirow[t]{3}{*}{ Homemade green peas and carrots in tomato sauce } & 3.00 & 0.92 & 90 & $92 \pm 7$ \\
\hline & & & 60 & $90 \pm 4$ \\
\hline & & & 30 & $89 \pm 5$ \\
\hline \multirow[t]{3}{*}{ Corn } & 1.00 & 0.50 & 30 & $90 \pm 5$ \\
\hline & & & 10 & $92 \pm 2$ \\
\hline & & & 5 & $91 \pm 3$ \\
\hline \multirow[t]{3}{*}{ Sliced Pears light syrup } & 1.00 & 0.44 & 10 & $94 \pm 3$ \\
\hline & & & 3 & $94 \pm 5$ \\
\hline & & & 1 & $93 \pm 6$ \\
\hline
\end{tabular}

Chromatographic Conditions and MS Detection. In the GC-MS (Agilent 6890 series II gas chromatograph with autosampler injector series 7683 and Agilent 5973 N [MSD]), an optima Delta-3 capillary column $(25 \mathrm{~m} \times 0.20 \mathrm{~mm} \times$ $0.20 \mu \mathrm{m})$ with helium as a carrier gas were used. A $2 \mu \mathrm{L}$ injection volume with pulsed split-less mode for $0.08 \mathrm{~min}$ at a constant flow of $20 \mathrm{~mL} / \mathrm{min}$ was employed with column flow rate at $1 \mathrm{~mL} / \mathrm{min}$. The injector temperature was set at $285{ }^{\circ} \mathrm{C}$, auxiliary (transfer line) at $285^{\circ} \mathrm{C}$, and the oven temperature program was as follows: $120{ }^{\circ} \mathrm{C}$ (held for $2 \mathrm{~min}$ ), ramp at $10^{\circ} \mathrm{C} / \mathrm{min}$ to $275^{\circ} \mathrm{C}$ (held for $3 \mathrm{~min}$ ). The mass spectrometer source was operated in the electron impact ionization mode (EI) at $70 \mathrm{eV}$ and $230{ }^{\circ} \mathrm{C}$ whereas the mass analyzer was operated in the SIM mode at $150{ }^{\circ} \mathrm{C}$ for better sensitivity, selectivity, and matrix effect eliminating. Calibration of the mass spectrometer was performed by autotuning mode in Chemstation software using perflourotributylamine (PFTBA) with tuning masses $(69 / 219 / 502)$. The monitored ions $(\mathrm{m} / \mathrm{z})$ for the diacetyl derivative of both BPA- $\mathrm{d}_{16}$ and BPA were 224/242/284 and $213 / 228 / 312$ as obtained from GC-MS spectra in the scan mode of a standard mixture of diacetylated BPA- $\mathrm{d}_{16}$ and BPA, respectively, whereas retention times were $17.06 \pm 0.02 \mathrm{~min}$ and $17.19 \pm 0.03 \mathrm{~min}$, respectively, as indicated in Figure 1.

Linear Calibration Curve Standards. Stock solutions of BPA $(10.0 \mathrm{mg} / \mathrm{L})$ and BPA-d ${ }_{16}(10.0 \mathrm{mg} / \mathrm{L})$ were prepared by weighing accurately the exact amount of each using microbalance (MXA5, RADWAG, Poland) and dissolved in $0.25 \mathrm{M} \mathrm{K}_{2} \mathrm{CO}_{3} / 0.1 \mathrm{M} \mathrm{NaOH}$ solution, where appropriate dilutions were made to end up with the working standards. Diacetylated BPA ten calibration standards $(1-750 \mu \mathrm{g} / \mathrm{L})$ were obtained by serial dilutions of the BPA stock solution and working standard $(1.0 \mathrm{mg} / \mathrm{L})$ with $0.25 \mathrm{M} \mathrm{K}_{2} \mathrm{CO}_{3} / 0.1 \mathrm{M}$ $\mathrm{NaOH}$ solution. Each individual standard was subjected to the above mentioned procedure.
Linear Range. For the calculation of the performance data, a calibration was carried out with ten concentration levels of PBA in the range from 1 to $500 \mu \mathrm{g} / \mathrm{L}$ and up to $750 \mu \mathrm{g} / \mathrm{L}$ in addition to the blank, where a plot of concentration of BPA vs. BPA/BPA- $\mathrm{d}_{16}$ area ratio from mass detector was plotted. From the resulting calibration curve, the regression coefficient was calculated, characterizing the linearity of the calibration function. The coefficient of determination was 0.998, indicating a very good linearity of the calibration function in this concentration range.

Instrumental Detection Limit and Limit of Quantitation. The instrument detection limit (IDL) was obtained by diluting the standard mixture solution until the ratio of signal to noise $(S / N)$ is equal to 3 , while the limit of quantitation (LOQ) was calculated as $(S / N)$ ratio equal to 10 . The calculated IDL was $0.01 \mu \mathrm{g} / \mathrm{L}$, and LOQ was $0.034 \mu \mathrm{g} / \mathrm{L}$. LOQ was verified to be within the linearity dynamic range.

Method Detection Limit, Repeatability, and Recovery. The method detection limit (MDL) was calculated using the following equation:

$$
\mathrm{MDL}=t(n-1,1-\alpha=0.99) \times \mathrm{SD}
$$

where SD is the standard deviation of seven replicates of a definite spiked sample concentration in $\mu \mathrm{g} / \mathrm{kg}, t$ is the degrees of freedom, $n$ is the number of replicates, and $\alpha$ is the confidence level $(t=3.143$ for $n=7$ at 99\%). Homemade samples (not canned) were tested to be void of BPA including homemade chick peas, Medames Fava Beans, farm condensed milk, sausages from Butchery, corn from farmers market, and homemade green peas and carrots, which were spiked with four concentration levels $(0.4 \mu \mathrm{g} / \mathrm{kg}, 1.0 \mu \mathrm{g} / \mathrm{kg}, 3.0 \mu \mathrm{g} / \mathrm{kg}$, and $5.0 \mu \mathrm{g} / \mathrm{kg}$ ) of BPA, then extracted and acetylated as in the abovementioned procedure for GC-EI/MS in the SIM mode 


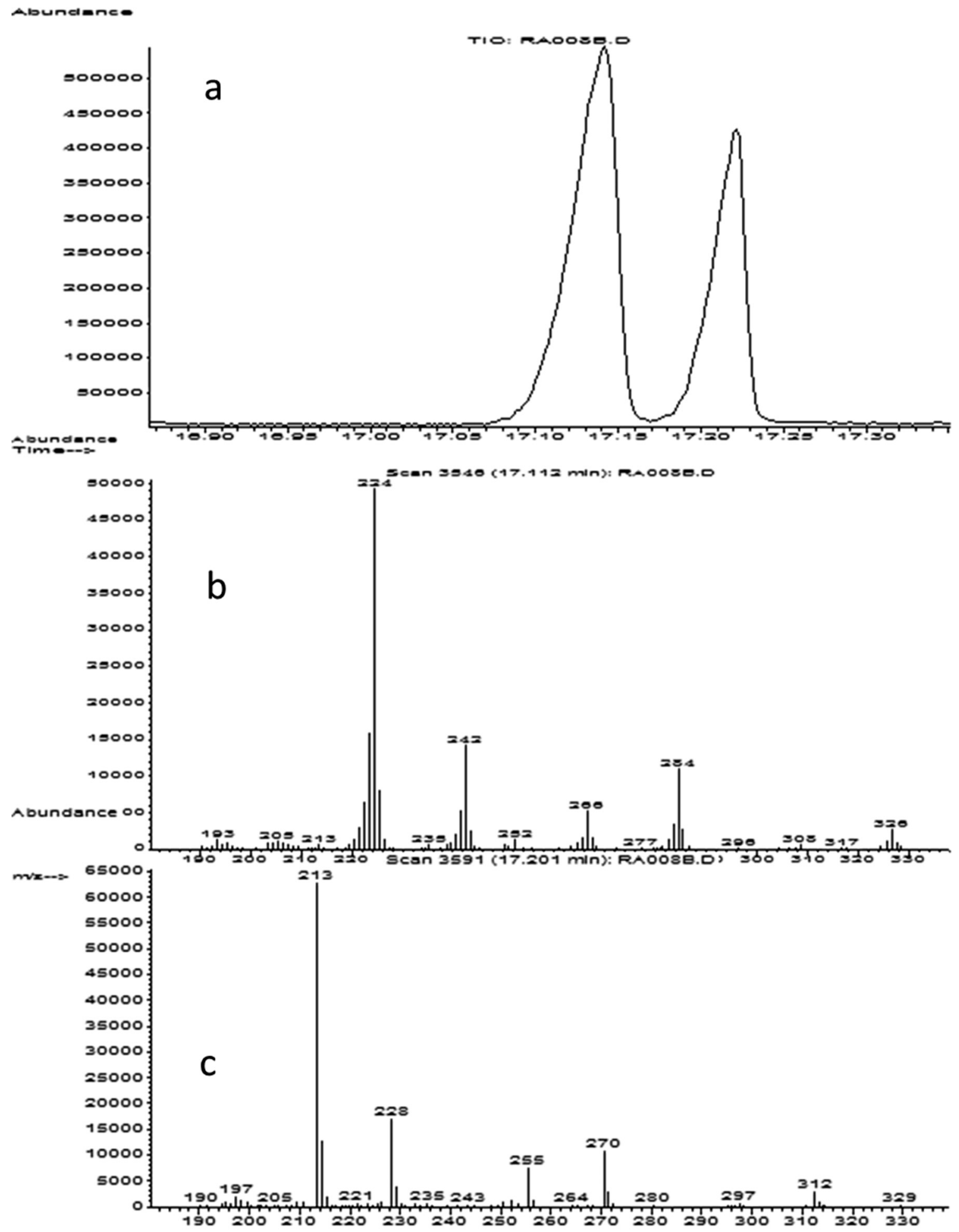

$m z=->$

Figure 1. GC-EI/MS total ion chromatogram (TIC) of a standard mixture of diacetylated BPA- $\mathrm{d}_{16}$ and BPA respectively in the scan mode (a) mass-spectra of the diacetylated derivatives of BPA- $\mathrm{d}_{16}$ (b) and BPA (c)

analysis. For other matrices, canned food samples were spiked with the appropriate level of BPA. Also, average recoveries were calculated $(n=3)$ for the above void BPA samples by spiking them with appropriate BPA concentration (three concentration levels) close to the concentration found in real canned foods as in indicated in Table 1 . The repeatability and intermediate precision were evaluated at three concentration levels $(1 \mu \mathrm{g} / \mathrm{kg}, 30 \mu \mathrm{g} / \mathrm{kg}$, and $90 \mu \mathrm{g} / \mathrm{kg})(n=6)$. The calculated MDL values ranged from $0.3 \mu \mathrm{g} / \mathrm{kg}$ (homemade check peas) to $3.2 \mu \mathrm{g} / \mathrm{kg}$ (farm condensed milk), whereas the recovery ranged from $85 \%$ (sardines) to $94 \%$ (Sliced Pears in light syrup) with the relative standard deviations (RSDs) of $2 \%-13 \%$ as indicated in Table 1.

\section{Results and Discussion}

The obtained BPA quantitative GC-EI/MS results for the tested canned foods are summarized in Tables 2 and 3 indicated with the food type and manufacturing country with final units in $\mu \mathrm{g} / \mathrm{kg}$. Samples were injected in triplicate with $50 \%$ of the samples prepared in duplicate in addition to method blanks. The levels of PBA in the samples were ranged from $<\mathrm{MDL}$ to 
Table 2. BPA concentrations in different types of canned food with their labeling detailed information

\begin{tabular}{|c|c|c|c|c|c|c|c|}
\hline Product name/country & $\begin{array}{c}\text { Average } \\
\mathrm{BPA} \pm(\mathrm{SD}) \\
(\mu \mathrm{g} / \mathrm{kg})\end{array}$ & $\mathrm{pH}^{a}$ & Sugar $^{b}$ & Protein $^{b}$ & Sodium $^{b}$ & Lipids $^{b}$ & $\begin{array}{c}\text { 2- or 3-piece/lacquered } \\
\text { part }\end{array}$ \\
\hline Luna cream $/ \mathrm{KSA}$ & $28.1 \pm(2.1)$ & 5.50 & 3.0 & 1.5 & & 21.0 & $\begin{array}{l}\text { 2-piece/all lacquered } \\
\text { with light grey-white }\end{array}$ \\
\hline Sliced Pears light syrup/China & $<\mathrm{MDL}$ & 3.80 & $c$ & c & $c$ & $c$ & $\begin{array}{c}\text { Glass jar with metallic } \\
\text { lid/lacquered } \\
\text { white from inside }\end{array}$ \\
\hline Hummus tahini/Al-Rawabi/Jordan & $12.6 \pm(1.7)$ & 4.50 & $c$ & 7.3 & 0.32 & 1.8 & $\begin{array}{l}\text { 3-piece/all pieces } \\
\text { coated white }\end{array}$ \\
\hline Cucumber in brine/Zadona/Palestine & $6.6 \pm(0.4)$ & 4.60 & 3.0 & 2.0 & 0.99 & 0.6 & $\begin{array}{l}\text { 3-piece/all pieces } \\
\text { coated white }\end{array}$ \\
\hline Whole artichoke hearts/Lariqueza Espanola/Spain & $16.2 \pm(1.2)$ & 4.50 & 1.0 & 3.0 & 0.400 & 0.0 & $\begin{array}{l}\text { 3-piece/all pieces } \\
\text { coated white }\end{array}$ \\
\hline Artichoke hearts/Spain & $13.4 \pm(0.9)$ & 4.50 & 8.0 & 1.6 & 0.402 & 0.12 & $\begin{array}{l}\text { 3-piece/all pieces } \\
\text { coated white }\end{array}$ \\
\hline Hearts of palm/Ecuador & $10.3 \pm(1.1)$ & 4.50 & 5.0 & 2.0 & 0.290 & 0.0 & $\begin{array}{l}\text { 3-piece/all pieces } \\
\text { coated white }\end{array}$ \\
\hline Luna Chick peas/Jordan & $57.4 \pm(2.6)$ & 5.55 & 0.6 & 6.6 & 0.295 & 1.9 & $\begin{array}{l}\text { 2-piece/all grey } \\
\text { white and lid white }\end{array}$ \\
\hline Green peas and carrots/Al-rawabi/Jordan & $16.1 \pm(1.8)$ & 5.50 & 22.5 & 7.3 & 0.32 & 1.8 & $\begin{array}{l}\text { 3-piece/all grey white } \\
\text { and lid white lacquering }\end{array}$ \\
\hline Green peas/Luna/Jordan & $42.2 \pm(2.2)$ & 5.70 & 11.0 & 5.2 & 0.760 & 0.0 & $\begin{array}{l}\text { 2-piece/all grey white } \\
\text { and lid white lacquering }\end{array}$ \\
\hline Peaches halves in syrup/South Africa & $<$ MDL & 3.95 & $\begin{array}{l}\text { 26/per } 140 \mathrm{~mL} \\
\text { serving }\end{array}$ & 1 & 0.000 & 0.0 & $\begin{array}{c}\text { 2-piece } \\
\text { (unlined tin plated steel) }\end{array}$ \\
\hline Beets sliced/USA & n.d. & 5.10 & $\begin{array}{c}8.0 / 120 \mathrm{~g} \\
\text { serving }\end{array}$ & $<1 \mathrm{~g}$ & 0.250 & $c$ & $\begin{array}{c}\text { 2-piece/all } \\
\text { yellowish-lacquering }\end{array}$ \\
\hline Cheddar cheese/Bahrain & $2.2 \pm(0.8)$ & - & 1.0 & 16.5 & 1.73 & 24.5 & $\begin{array}{l}\text { 2-piece easy } \\
\text { pull lid/excluding } \\
\text { lid lining is white }\end{array}$ \\
\hline Zawan cocktail sausages chicken/Holland & $<\mathrm{MDL}$ & 6.00 & 4.5 & 11.0 & $c$ & 12.5 & $\begin{array}{l}\text { No grey or white lining } \\
\text { (may be tin plated steel) }\end{array}$ \\
\hline Plain Fava beans/UAE & $30.7 \pm(1.6)$ & 5.70 & 15.0 & 7.0 & 0.430 & 1.0 & $\begin{array}{l}\text { 3-piece/all pieces coated } \\
\text { with white lining }\end{array}$ \\
\hline $\begin{array}{l}{ }^{a} \text { Measured value. } \\
{ }^{b} \mathrm{~g} / 100 \mathrm{~g} \text { wet weight. } \\
{ }^{c} \text { Stands for not indicated. }\end{array}$ & & & & & & & \\
\hline
\end{tabular}

$57.4 \pm(2.6) \mu \mathrm{g} / \mathrm{kg}$ with some samples labeled as n.d. (not detected). Two of the samples that indicated with n.d. were rice and beans, and chili made with organic black beans, where their labeling indicated BPA-free lining. These two samples were used as quality control (QC) standards after spiking with $1 \mu \mathrm{g} / \mathrm{kg}$ and $5 \mu \mathrm{g} / \mathrm{kg}$ of BPA as indicated in Table 1. Both samples showed relative errors of $-8 \%$ which are within the food analysis criteria. Also, all spiked samples in Table 1 showed recovery values from $85 \%$ (sardines) to $94 \%$ (Sliced Pears in light syrup) with relative standard deviations (RSDs) of $2 \%-13 \%$ affirming the trueness of the method according to the guidelines for performance criteria and validation procedures of analytical methods used in controls of food contact materials [30]. The obtained recovery values in this study especially for food samples with high fat content like sardines $(85 \pm 5)$ were lower than those reported by Kawamura and coworkers in 2014 (recovery $=97.1 \pm 4.4$ ) [22] employing methanol as extracting solvent and hexane for cleanup step and fat removal, but higher than reported recoveries by Cunha and coworkers in 2013 (recovery $=77 \%$ at $5 \mu \mathrm{g} / \mathrm{kg}$ spiking level) [28] employing heptane for fat removal, acetonitrile, and solid sorbent for BPA extraction. The samples with BPA concentrations $<$ MDL were in glass containers or cans that are void from any BPA lining like tin, gold plated, or steel plating. This indicated also that raw food (before canning) contamination with BPA was minor and could be coming from different sources. Regarding the meat tuna in salted water (tin plated can produced in Thailand) and light meat tuna chunks in vegetable oil (Thailand), the BPA concentrations were $2.6 \mu \mathrm{g} / \mathrm{kg}$ and $2.7 \mu \mathrm{g} / \mathrm{kg}$ respectively which are a little bit higher the than the MDL $(2.5 \mu \mathrm{g} / \mathrm{kg})$ which could be attributed to minor cross contamination from other source (production line, sea). Other samples ranged from $2.2 \pm(0.8) \mu \mathrm{g} / \mathrm{kg}$ (cheddar cheese) to $52.3 \pm(2.5) \mu \mathrm{g} / \mathrm{kg}$ (chick peas) where most of these canned foods had in common; the 3-piece can with white color lacquered heavily from inside (most of them produced in Jordan, United Arab Emirates, and Kingdom of Saudi Arabia). The most striking feature of the analysis is that all Medames Fava Beans and chick peas or hummus cans are those with the highest BPA concentrations reaching maximum value of $57.4 \pm(2.6) \mu \mathrm{g} / \mathrm{kg}$ and minimum value of $12.6 \pm(1.7) \mu \mathrm{g} / \mathrm{kg}$ with an average value of $38.2 \pm$ (3.1) $\mu \mathrm{g} / \mathrm{kg}$. These relatively high results were expected since these food cans were totally lacquered heavily from inside with the white lining (epoxy resins that leaches BPA) with adequate solution salinity, in addition to the manufacture production step that involves adding hot fava beans or chick peas after passing frying machine to the cans ending with sterilization step (heating under steam), which give ideal conditions for BPA to leach from resin. They could be consumed in daily basis with an average consumption of $250 \mathrm{~g}$ per person (traditional meal) in Middle East and Africa region (MENA). Canned green peas samples also showed BPA concentrations of $42.2 \pm(2.2) \mu \mathrm{g} / \mathrm{kg}$ (2 pieces/ all grey white and lid white lacquering that are epoxy resins that could leach BPA). Still, in this research, one of the aims was to investigate the concentrations of BPA in different food types without further going in correlations to food type and food ingredients. According to a small-scale consumer questioner and market survey on canned foods in Jordan, the most sold and consumed items are fava beans, chick peas or hummus, tuna and sardines, corn and baby corn, sliced black olives, and finally condensed milk. Still, no knowledge is available about the true quantities consumed daily. The measured obtained maximum BPA values using the developed method are lower than those values reported in other countries like Canada [9], New Zealand [31], Belgium [32], Portugal [28], Turkey [19], US [33], UK [34], and 
Table 3. Continue BPA concentration in different types of canned food with their labeling detailed information

\begin{tabular}{|c|c|c|c|c|c|c|c|}
\hline Product name & $\begin{array}{c}\text { Average } \\
\mathrm{BPA} \pm(\mathrm{SD}) \\
(\mu \mathrm{g} / \mathrm{kg})\end{array}$ & $\mathrm{pH}^{a}$ & Sugar $^{b}$ & Protein $^{b}$ & Sodium $^{b}$ & Lipids $^{b}$ & $\begin{array}{c}\text { 2- or 3-piece/lacquered } \\
\text { part }\end{array}$ \\
\hline Chick peas/Red rose/Jordan & $52.3 \pm(2.5)$ & 5.68 & $c$ & $c$ & $c$ & c & $\begin{array}{l}\text { 2-piece/all lacquered } \\
\text { with white lining }\end{array}$ \\
\hline Medames Fava Beans/UAE & $35.8 \pm(2.2)$ & 5.58 & $\begin{array}{c}17.38 / \text { per } \\
150 \text { g serving }\end{array}$ & 8.3 & 0.499 & 2.3 & $\begin{array}{l}\text { 2-piece/all lacquered } \\
\text { with white lining }\end{array}$ \\
\hline Medames Fava large Beans/UAE & $32.9 \pm(1.8)$ & 5.58 & $\begin{array}{c}18.45 / \text { per } \\
150 \text { g serving }\end{array}$ & 8.3 & 0.610 & 2.0 & $\begin{array}{l}\text { 2-piece/all lacquered } \\
\text { with white lining }\end{array}$ \\
\hline Sliced black olives/Spain & $12.5 \pm(0.1)$ & 6.56 & $\begin{array}{l}2.0 / 30 \mathrm{~g} \\
\text { serving }\end{array}$ & 0.0 & 0.262 & 3.0 & $\begin{array}{l}\text { 2-piece with pull open } \\
\text { top lid (excluding lid white } \\
\text { lining from inside) }\end{array}$ \\
\hline Spiced sardines in vegetable oil/Morocco & $<\mathrm{MDL}$ & 6.35 & 0.00 & 22.3 & 0.24 & 8.3 & $\begin{array}{l}\text { 2-piece tin plated steel } \\
\text { with easy open lid }\end{array}$ \\
\hline Sweetened Condensed milk/Germany & n.d. & 6.30 & 56.5 & 7.1 & 0.300 & 8.0 & $\begin{array}{l}\text { 2-piece tin plated steel } \\
\text { with pull open lid }\end{array}$ \\
\hline meat tuna in salted water/Thailand & $2.6 \pm(0.8)$ & 6.40 & 0.00 & 27 & 1.0 & 0.5 & $\begin{array}{l}\text { 2-piece easy open lid } \\
\text { enameled tin plated lining }\end{array}$ \\
\hline $\begin{array}{l}\text { Chili made with organic black beans } \\
\text { and spices/USA }\end{array}$ & n.d. & 5.60 & $\begin{array}{c}36 / \text { per } \\
250 \text { serving }\end{array}$ & 10 & 0.48 & 2.0 & Labeled BPA free lining \\
\hline Rice and beans/USA & n.d. & 6.12 & $\begin{array}{l}21 / \text { per } \\
130 \text { serving }\end{array}$ & 4.0 & 0.200 & 1.0 & Labeled BPA free lining \\
\hline Whole baby corn in brine/Thailand & $15.1 \pm(1.3)$ & 5.00 & $\begin{array}{c}8 \mathrm{~g} / \mathrm{per} \\
115 \mathrm{~g} \\
\text { serving }\end{array}$ & $\begin{array}{l}3 \mathrm{~g} / \mathrm{per} \\
115 \mathrm{~g} \\
\text { serving }\end{array}$ & $\begin{array}{l}270 \mathrm{mg} / \mathrm{per} \\
115 \mathrm{~g} \\
\text { serving }\end{array}$ & 0.0 & $\begin{array}{l}\text { 2-piece easy open lid } \\
\text { grey-white lining }\end{array}$ \\
\hline $\begin{array}{l}\text { Light meat tuna chunks in vegetable } \\
\text { oil/Thailand }\end{array}$ & $2.7 \pm(0.8)$ & 5.7 & 0.0 & 25 & $400 \mathrm{mg} / 100 \mathrm{~g}$ & 5.7 & $\begin{array}{l}\text { 2-piece drawn and } \\
\text { ironed steel }\end{array}$ \\
\hline Red kidney beans/Italy & n.d. & 5.80 & $\begin{array}{l}5.3 \mathrm{~g} / 100 \mathrm{~g} \\
\text { serving }\end{array}$ & $\begin{array}{l}4.4 \mathrm{~g} / 100 \mathrm{~g} \\
\text { serving }\end{array}$ & $\begin{array}{l}300 \mathrm{mg} / 100 \mathrm{~g} \\
\text { serving }\end{array}$ & $0.3 \mathrm{~g}$ & $\begin{array}{l}\text { 2-piece tin plated steel } \\
\text { with pull open lid }\end{array}$ \\
\hline Chicken luncheon meat/Holland & n.d. & - & $7 \mathrm{~g} / 100 \mathrm{~g}$ & $12 \mathrm{~g} / 100 \mathrm{~g}$ & - & $15 \mathrm{~g} / 100 \mathrm{~g}$ & $\begin{array}{l}\text { 2-piece tin plated steel } \\
\text { with pull open lid }\end{array}$ \\
\hline Papaya in syrup/Thailand & $<\mathrm{MDL}$ & 4.00 & $11.3 \mathrm{~g} / 100 \mathrm{~g}$ & $<1 \mathrm{~g}$ & $c$ & 0.00 & $\begin{array}{l}\text { 3-piece can, interior } \\
\text { coating gold }\end{array}$ \\
\hline $\begin{array}{l}{ }^{a} \text { Measured value. } \\
{ }^{b} \text { g per } 100 \mathrm{~g} \text { wet weight. } \\
{ }^{c} \text { Stands for not indicated. }\end{array}$ & & & & & & & \\
\hline
\end{tabular}

France [35], but higher than that reported maximum BPA value in domestic canned food in Japan [22] as indicated in Table $S_{1}$. Also, the obtained results are much below the specific migration limit of $600 \mathrm{mg} / \mathrm{kg}$ set by EU commission (Commission Regulation EU 10/2011) [36]. With regard to sensitivity and linearity of the method, the lowest MDL obtained was $0.3 \mu \mathrm{g} / \mathrm{kg}$ based on $1 \mathrm{~g}$ portion of the sample which is comparable with previously reported methods $[26,28]$ that employ the acetylation procedure at different conditions as shown in Table $S_{1}$. The linearity of the method was in between low and high linear calibration ranges reported in literature where some are shown in Table $S_{1}$. The developed method showed excellent validation for selectivity where the internal standard $\left(B P A-d_{16}\right)$ and target analyte (BPA) peaks were well resolved at retention times $17.06 \pm 0.02 \mathrm{~min}$ and $17.19 \pm 0.03 \mathrm{~min}$, respectively, in calibration standards and canned food samples with no interfering peaks. The aforementioned compounds were also confirmed with their finger print mass fragments $(224 / 242 / 284)$ and $(213 / 228 / 312)$, respectively, and employed method blank for subtraction as indicated for different samples in Figure 2 based on area ratio. Since varying trace or minor amounts of BPA were sometimes detected as expected in method blanks since BPA exists everywhere, one blank sample was carried out and analyzed for each batch of real samples as shown in Figure 2 and Figure $S_{2}$ where minor amounts of BPA in method blank in different batch were detected. The solvent extraction procedure was applicable in removing lipids, proteins, or any major interferences as noticed in Figure 2, where the method blank, spiked standard, and canned food sample shared the same background in the pre- and post-regions of BPA-d16 and BPA peaks in the GC chromatograms. The developed method showed good repeatability (RSDr $<7 \%, n=6$ ) and good intermediate precision (RSDw $<11, n=6$ ) not exceeding the acceptable criteria for precision $(\%$ relative standard deviation $[\mathrm{RSD}]=22.6 \%$ based on $100 \mu \mathrm{g} / \mathrm{kg}$ concentration [30]. Also, canned food results had standard deviations (SDs) ranging from $0.42 \mu \mathrm{g} / \mathrm{kg}$ to $2.6 \mu \mathrm{g} / \mathrm{kg}$ which correspond to RSDs of $6.3 \%$ and $4.5 \%$, respectively.

\section{Conclusion}

The introduced analytical method (solvent extraction, acetylating, detection) developed in this study demonstrated to be reliable in terms of the low MDL $(0.3 \mu \mathrm{g} / \mathrm{kg})$ for BPA compared with other methods and closeness to other reported values. Also, the method showed excellent linearity $(0.034-750 \mu \mathrm{g} / \mathrm{L})$, accuracy expressed in recovery values $(85 \%-94 \%)$, trueness as demonstrated by relative error of $-8 \%$ for QC standards after spiking with $1 \mu \mathrm{g} / \mathrm{kg}$ and $5 \mu \mathrm{g} / \mathrm{kg}$ of BPA, repeatability (RSDr $<7 \%, n=6$ ), and good intermediate precision (RSDw $<11, n=6$ ), according to the guidelines for performance criteria and validation procedures of analytical methods used in controls of food contact materials. It also demonstrated simplicity, relative short time of analysis (18 min run time), and cheapness and availability of chemicals, especially for acetic anhydride which is a cheap and available derivatization reagent with boiling point at $139.8^{\circ} \mathrm{C}$ that is convenient for use with mass detectors and a useful alternative for silylation. In addition to the possibility of application to a wide range of food types, the BPA concentrations ranged from $<\mathrm{MDL}$ to $57.4 \pm(2.6) \mu \mathrm{g} / \mathrm{kg}$ with the highest content found in chick peas or hummus cans in addition to green peas $(42.2 \pm(2.2) \mu \mathrm{g} / \mathrm{kg})$. The method provides an alternative procedure for BPA extraction utilizing alkaline solution of $\left(0.25 \mathrm{M} \mathrm{K}_{2} \mathrm{CO}_{3} / 0.10 \mathrm{M} \mathrm{NaOH}\right)$ instead of using the most common used organic solvents like acetonitrile and methanol. Also, it provides a cleanup step by lowering the $\mathrm{pH}$ to 4 followed by diethyl ether extraction similar to using 


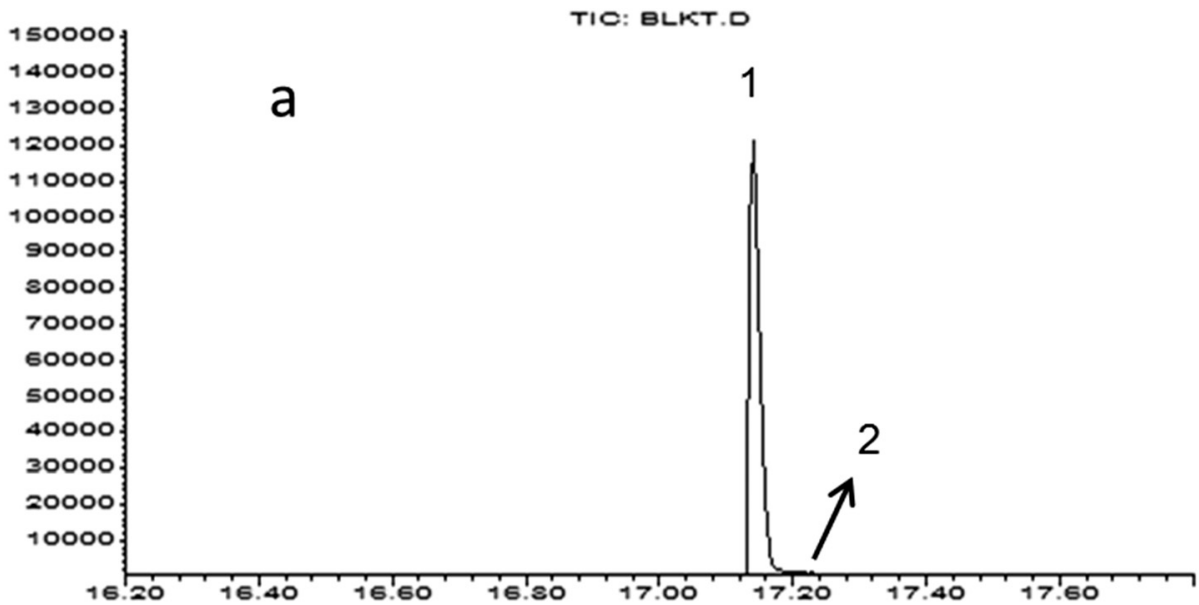

Time---
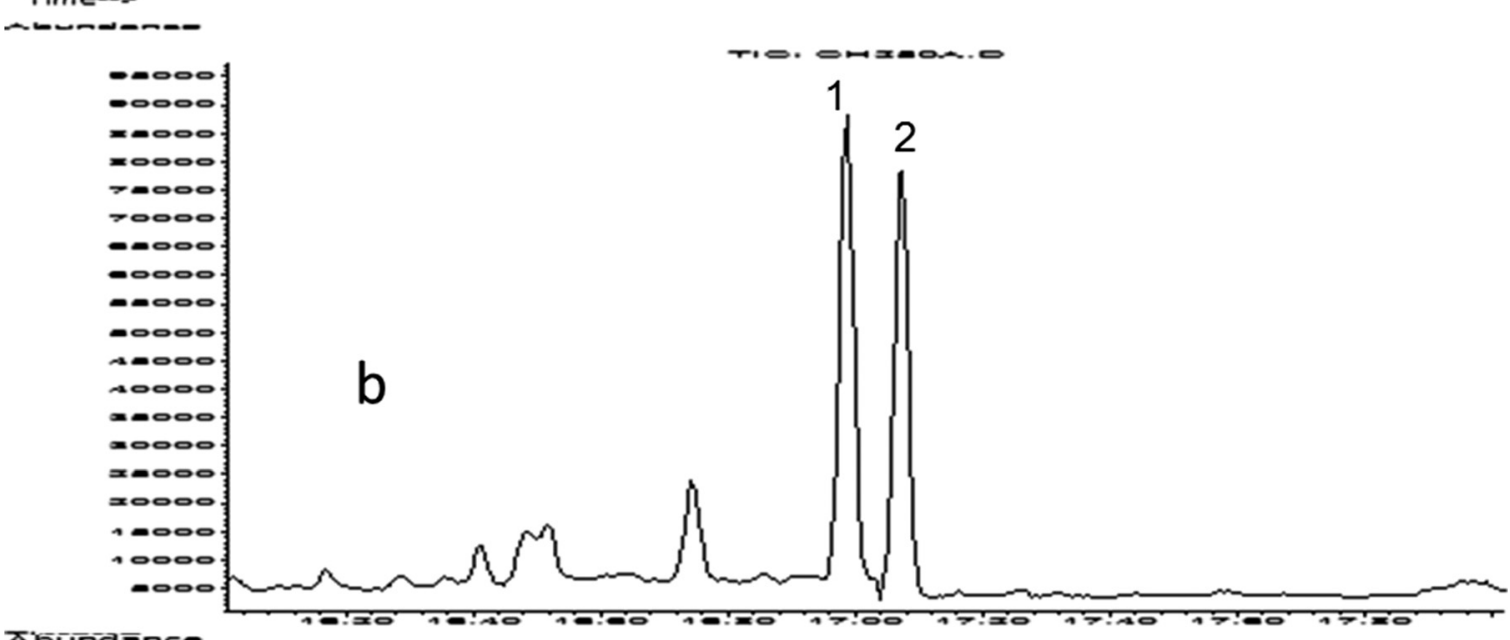

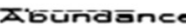

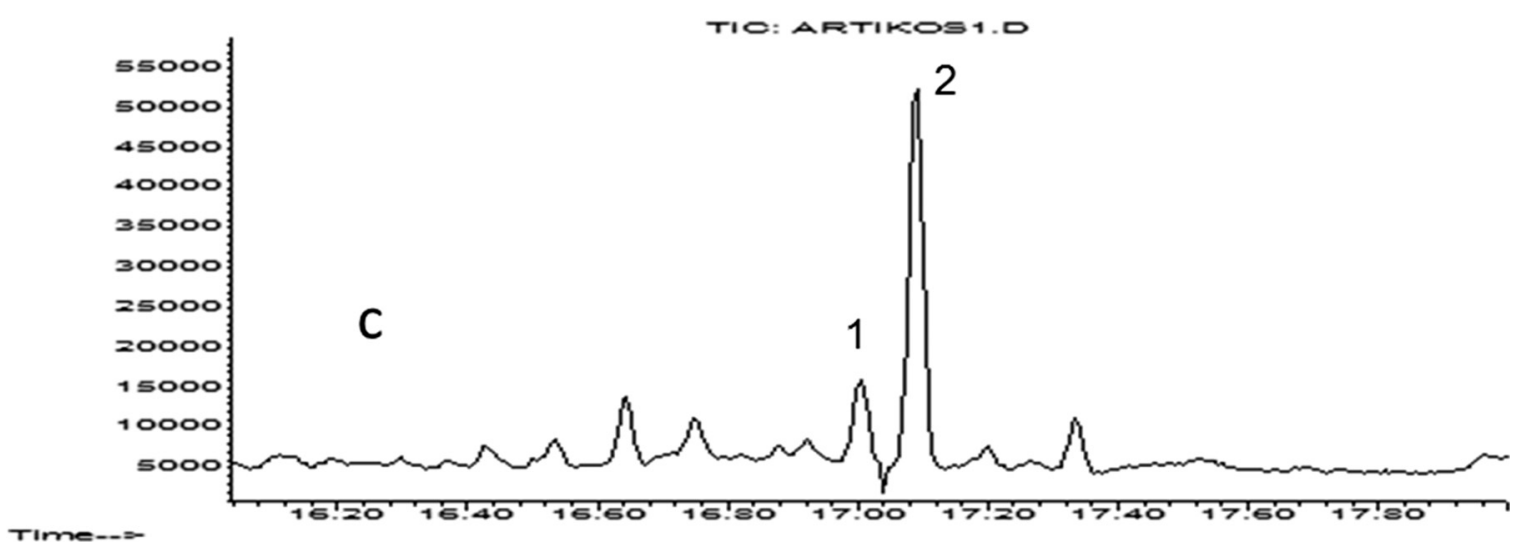

Figure 2. GC-EI/MS in the SIM mode chromatogram of (a) method blank, (b) $250 \mu \mathrm{g} / \mathrm{L}$, calibration standard, and (c) artichoke hearts sample, where peaks 1 and 2 correspond to diacetylated derivatives of BPA- $\mathrm{d}_{16}$ and BPA, respectively

organic solvents like cyclohexane or solid-phase extraction (SPE). The detected levels of BPA found in this study were much below the specific migration limit of $600 \mathrm{mg} / \mathrm{kg}$ set by EU Commission (Commission Regulation EU 10/2011). Still, in the future, a more comprehensive food survey of BPA with detailed information about most consumed and purchased items as well as their daily consumption amounts, employing independent analytical methods in all types of canned foods, is needed in the Jordanian market to build an exposure risk assessment model that includes daily intake from different canned food items in units of $\mu \mathrm{g} / \mathrm{kg} / \mathrm{day}$. This will help to draw a general conclusion and raise consumer awareness about BPA concentrations in canned food, frequent monitoring of BPA in canned food, and urging legislation agencies in Jordan to obligate food industry to use alternatives to BPA can linings. To our knowledge, this is the first study of its kind to be conducted in Jordan.

Acknowledgments. The authors greatly acknowledge the Deanship of Academic Research at the University of Jordan for the financial support.

\section{References}

1. Cao, X. L. Background paper on chemistry and analytical methods for determination of Bisphenol $A$ in food and biological samples WHO/HSE/FOS 11.1.0 FAO/WHO expert meeting on Bisphenol A. Canada, 2010. 
2. Baily, A. B.; Hoeksta, E. J. Background paper on: Sources and occurrence of Bisphenol A relevant exposure of consumers WHO/HSE/FOS 11.1 FAO/WHO expert meeting on Bisphenol A. Canada, 2010.

3. LaKind, J. S. Int. J. Technol. Pol. Manage. 2013, 13, 80.

4. Poustka, J.; Dunovská, L.; Hajšlová, J.; Holadová, K.; Poustková, I. Czech J. Food. Sci. 2007, 25, 421-429.

5. Markey, C. M.; Rubin, B. S.; Soto, A. M.; Sonnenschein, C. J. Steroid. Biochem. Mol. Biol. 2002, 83, 235-244.

6. Usman, A.; Masood, A. Chemosphere 2016, 158, 131-142.

7. Lyons, G. Bisphenol A, a known endocrine disrupter A WWF European Toxics Programme Report, 2000.

8. Calfat, A. M.; Wong, Y.-X.; Reidy, L. Y.; Needham, L. L. Environ Health Perspect. 2008, 116, 39-44.

9. Cao, XL. J. Liq. Chromatogr. Relat. Technol. 2012, 35, 2795-2829.

10. Voutsa, A. Analytical methods for determination of Bisphenol A In

Eliades, T., Eliades, G. (ed) Plastics in dentistry and estrogenisity, part II; Springer: Berlin Heidelberg, 2013, pp. 51-77.

11. Rozaini, M. N. H.; Yahaya, N.; Saad, B.; Kamaruzaman, S.; Hanapi, N. S. M. Talanta. 2017, 171, 242-249.

12. Cunha, S. C.; Oliveira, C.; Fernandes, J. O. Anal. Bioanal Chem. 2017, 409, 151-160.

13. Pasquale, G.; Pisciottano, I. D. M.; Francesco, E.; Evelina, F.; Gelsomina, S.; Mita, G. D.; Damiano, M. G.; Teresa, C. Food Chem. 2017, 220, 406-412.

14. Faraji, M.; Noorani, M.; Sahneh, B. N. Food Anal. Methods. 2017, 10,764-772.

15. Kamalabadi, M.; Mohammadi, A.; Alizadeh, N. Talanta. 2016, 156-57, $147-153$.

16. Vavrous, A.; Lukas, V.; Jitka, S.; Kristina, K.; Karel, V.; Dagmar, J. Food Control. 2016, 60, 221-229.

17. Shuangqiao, J.; Yaling, Y.; Mousheng, L. Anal. Lett. 2015, 48, 1830-1841.

18. Li, Y.; Jiao, Y.; Guoc, Y.; Yang, Y. Anal. method 2013, 5, 5037-5043.

19. Sungur, S.; Koroglu, M.; Ozkan, A. Food Chem. 2014, 142, 87-91.

20. Orata, F. Derivatization reactions and reagents for gas chromatography analysis In: Mohd, M. A. (Ed) advanced gas chromatography - progress in agricultural, biomedical and industrial applications, ISBN: 978-953-51-0298-4. InTech, 2012; pp. 83-108. Available from: http://www.intechopen.com/books/ advanced-gaschromatography-progress-in-agricultural-biomedical-and-industrialapplications/derivatization-reactions-andreagents-for-gas-chromatography-analysis.

21. Ruiz-Matutea, A. I.; Hernández, O.; Rodríguez-Sánchez, S.; Sanz,

M. L.; Castro, M. J. Chromatogr. B 2011, 879, 1226-1240.

22. Kawamura, Y.; Etoh, M.; Hirakawa, H.; Abe, Y.; Mutsuga, M. Food Addit. Contam. Part A 2014, 31, 330-340.

23. Jurek, A.; Leitner, E. Food Addit. Contam: Part A 2015, 32, 1331-1342.

24. Arar, S.; Vinogradov, E.; Shewmaker, P. L.; Monteiro, M. A. Carbohyd. Res. 2008, 343, 1079-1090.

25. Cesen, M.; Lambropoulou, D.; Laimou-Geraniou, M.; Kosjek, T.; Blaznik, U.; Heath, D.; Heath, E. J. Agri. Food Chem. 2016, 64, 8866-8875.

26. Cao, X. L.; Perez-Locas, C.; Robichaud, A.; Clement, G.; Popovic, S.; Dufresne, G.; Dabeka, R. W. Food Addit. Contam. Part A 2015, 32, 2154-2160.

27. Cao, X. L.; Dufresne, G.; Belisle, S.; Clement, G.; Falicki, M.; Beraldin, F.; Rulibikiye, A. J. Agri. Food Chem. 2008, 56, 7919-7924.

28. Cunha, S. C.; Fernandes, J. O. Food Control. 2013, 33, 549-555.

29. Fontana, A. R.; Munoz de Toro, M.; Altamirano, J. C. J. Agri. Food Chem. 2011, 59, 3559-3565.

30. Bratinova, S.; Raffael, B.; Simoneau, C. Guidelines for performance criteria and validation procedures of analytical methods used in controls of food contact materials. JRC scientific and technical reports 2009; EUR 24105 EN - 1st edition.

31. Thomson, B. M.; Grounds, P. R. Food Addit. Contam. 2005, 22, $65-72$.

32. Geens, T.; Apelbaum, T. Z.; Goeyens, L.; Neels, H.; Covaci, A. Food Addit. Contam. Part A 2010, 27, 1627-1637.

33. Schecter, A.; Malik, N.; Haffner, D.; Smith, S.; Harris, T. R.; Paepke, O.; Birnbaum, L. Environ. Sci. Technol. 2010, 44, 9425-9430.

34. Goodson, A.; Summerfield, W.; Cooper, I. Food Addit. Contam. 2002, 19, 796-802.

35. Deceunincka, Y.; Bichona, E.; Duranda, S.; Bemrahc, N.; Zendonga, Z.; Morvana, M. L.; Marchanda, B. P.; Dervilly-Pinela, G.; Antignaca, J. P.; Leblancc, J. C.; Bizec, B. L. J. Chromatogr. A 2014, 1362, 241-249.

36. Commission regulation EU $10 / 2011$ on plastic materials and articles intended to come into contact with food 2009, Chapter 13, 045, 42-130. 